\title{
The Effect of Monovalent Cations on the Inhibition of Yeast Metabolism by Nystatin
}

\author{
By F. MARINI*, P. ARNOW AND J. O. LAMPEN \\ Institute of Microbiology, Rutgers, the State University, New Brunswick, \\ Nero Jersey, U.S.A.
}

(Received 14 June 1960)

\begin{abstract}
SUMMARY
Glycolysis of yeast is inhibited by the polyene antibiotic nystatin. This inhibition was prevented or reversed at or above $\mathrm{pH} 5 \cdot 8$ (the approximate intracellular $\mathrm{pH}$ of yeast) by adding $\mathrm{NH}_{\mathbf{4}}^{+}, \mathrm{K}^{+}$or $\mathrm{Rb}^{+}$(in order of decreasing effectiveness). These ions do not interfere with the absorption of nystatin by the yeast cell. At pH 4 both glycolysis and respiration are highly sensitive to nystatin but are not protected by the monovalent cations. At $\mathrm{pH} 7$ respiration of intact cells was insensitive; only with yeast protoplasts could respiration be inhibited by nystatin. Temporary protection was obtained with $\mathrm{NH}_{4}^{+}$or $\mathbf{K}^{+}$.

$\mathrm{K}^{+}$and $\mathrm{NH}_{4}^{+}$did not prevent the fungicidal or fungistatic actions of nystatin even under conditions where the protection of glycolysis by these ions was essentially complete. The original yeast cells were not dependent upon added $\mathrm{K}^{+}$. After a brief treatment with nystatin at $\mathbf{p H ~} \mathbf{7 \cdot 0}$, the cells showed an absolute requirement for $\mathrm{K}^{+}$or $\mathrm{NH}_{4}^{+}$; it was shown that $\mathrm{K}^{+}$was rapidly lost by cells following contact with nystatin. It is concluded that nystatin directly damages the cell membrane and thus produces a rapid increase in permeability to small ions. The resulting depletion of cellular $\mathrm{K}^{+}$halts glycolysis. The addition of $\mathrm{K}^{+}$or $\mathrm{NH}_{4}^{+}$restores glycolysis but does not reverse the membrane alterations.
\end{abstract}

\section{INTRODUCTION}

Nystatin, a polyene antifungal antibiotic produced by Streptomyces noursei (Brown \& Hazen, 1957), inhibits growth and utilization of various substrates by fungi, especially yeast (Lampen, Morgan \& Slocum, 1957; Harman \& Masterson, 1957; Meyer-Rohm, Hopff \& Lange-Brock, 1957; Peynaud, Lafourcade \& Lafon, 1957; Bradley, 1958a, $b$ ). Lampen et al. (1957) reported that nystatin was more effective at acid than at neutral $\mathrm{pH}$ values in inhibiting glycolysis and respiration of Saccharomyces cerevisiae. The increased binding of nystatin by yeast at acid $\mathrm{pH}$ was suggested as a possible cause for the greater sensitivity of metabolism at this $\mathrm{pH}$. Evidence is now presented that this differential sensitivity is a function both of $\mathrm{pH}$ and of the monovalent cations in the test system.

* Present address: Laboratori Recerche Microbiologiae e Chemioterapia Farmitalia (Milano), Italy. 


\section{METHODS}

Organisms. Saccharomyces cerevisiae strain A-B was commercial bakers' yeast obtained from Anheuser Busch, Old Bridge, New Jersey, in the form of a pressed filter cake. The cells were washed four times in water before use.

Saccharomyces cerevisiae strain LK2G12 (obtained from Dr H. Halvorson, University of Wisconsin, Madison) was grown for $16 \mathrm{hr}$. on a slope of Penassay agar (Difco Laboratories, Inc., 920 Henry St, Detroit, Mich.) containing $1 \%(\mathrm{w} / \mathrm{v})$ glucose. The cells from one slope were transferred into $100 \mathrm{ml}$. of Wickerham's medium (Wickerham, 1951) and incubated for $16 \mathrm{hr}$. at $28^{\circ}$ on a rotary shaker. These cultures had an optical density of $c .1 .0$ at $530 \mathrm{~m} \mu$ when measured with the uninoculated medium as a blank. After washing twice with water, the cells (herein termed stationary-phase cells) were suspended in water at a concentration of $1 \times 10^{8} / \mathrm{ml}$., as determined by counts in a haemacytometer (American Optical Co., Buffalo, N.Y.). By using the method described by Cavett (1931), the nitrogen content of $1 \times 10^{8}$ cells ( $3 \mathrm{mg}$. dry weight) was found to be $c .0 .22 \mathrm{mg}$.

To prepare log-phase cells, $10 \mathrm{ml}$. of a stationary-phase culture was added to $100 \mathrm{ml}$. of Wickerham's medium and incubated as above for $4 \mathrm{hr}$. At this time an optical density of approximately 0.4 had been reached. The cells were washed twice with water and resuspended at a concentration of $1 \times 10^{8} / \mathrm{ml}$. Buds were counted as individual cells. It was found that $1 \times 10^{8}$ cells $(2 \mathrm{mg}$. dry wt.) contained c. $0.05 \mathrm{mg}$. N.

Protoplasts were obtained from log-phase cells by following essentially the technique described by Bachmann \& Bonner (1959) for Neurospora crassa. Before adding the snail enzyme to the cells, $0 \cdot 1 \mathrm{ml}$. of a $1 \%(\mathrm{w} / \mathrm{v})$ aqueous cysteine- $\mathrm{HCl}$ solution was added to each $\mathrm{ml}$. of enzyme to overcome the inhibitory effect of thiomersalate, present as a preservative in the commercial enzyme solution. The protoplasts were washed twice with sodium citrate + phosphate buffer $(\mathrm{pH} \mathrm{5.8)}$ plus $0.82 \mathrm{M}$-mannitol, and resuspended in buffered stabilizer solution. The nitrogen content was $c .0 .075 \mathrm{mg} . / 1 \times 10^{8}$ protoplasts.

Sensitivity tests. Defined medium $N$ of Vogel (1956) was used with the following additions, per 1 ., $10 \mathrm{~g}$. glucose, $2.0 \mathrm{mg}$. $i$-inositol, $0.2 \mathrm{mg}$. calcium pantothenate $0.2 \mathrm{mg}$. pyridoxine. $\mathrm{HCl}$ and $0.2 \mathrm{mg}$. thiamine. $\mathrm{HCl}$. A $50 \mathrm{ml}$. quantity of medium was inoculated with $0.5 \mathrm{ml}$. of a stationary-phase culture of strain LK2G 12. Nystatin was sterilized by the method of Donovick et al. (1955) and added aseptically to the autoclaved medium. The cultures were incubated for $16 \mathrm{hr}$. at $28^{\circ}$ on a rotary shaker. The criterion of growth was the optical density value at $660 \mathrm{~m} \mu$.

Manometry. The conventional Warburg respirometer was used at $30^{\circ}$. The contents of the flasks will be described below. Since $0.82 \mathrm{M}$-mannitol was present as an osmotic stabilizer in the experiments with protoplasts, it was generally added in tests with log-phase cells to permit direct comparison between the two cell types. The sensitivity of the log-phase cells to nystatin was increased somewhat by the addition of mannitol, but the characteristics of the inhibition did not appear to be altered. The sensitivity of stationary-phase cells was not affected by mannitol.

Preparation of materials. A highly purified preparation of nystatin (Lot HV 942, obtained from the Squibb Institute for Medical Research, New Brunswick, N.J.) was dissolved in dimethyl sulphoxide and diluted in water. The maximum concen- 
tration of dimethyl sulphoxide in any reaction mixture $(0.07 \%)$ had no detectable effect on metabolism. Buffers were prepared as described by Gomori (1955). $\mathrm{Na}^{+}$ was replaced in certain experiments by $\mathrm{K}^{+}$or $\mathrm{NH}_{4}^{+}$.

\title{
RESULTS
}

\section{Protection of glycolysis by potassium ions}

In the experiments previously reported (Lampen et al. 1957), the buffers used at neutral $\mathrm{pH}$ value contained considerable quantities of both sodium and potassium ions. In subsequent tests with only a single cation present (Table 1 ), it became evident that glycolysis was highly sensitive to nystatin at $\mathrm{pH} 7 \cdot 0$ in $\mathrm{Na}^{+}$-buffer, but was unaffected in $\mathrm{K}^{+}$-buffer. At $\mathrm{pH} 4.0$ there was no significant protection by $\mathrm{K}^{+}$. The amount of nystatin absorbed by the cells was the same whether $\mathrm{Na}^{+}$or $\mathrm{K}^{+}$was present (Table 1 ); thus $\mathrm{K}^{+}$did not protect by preventing the access of nystatin to the yeast cells. More nystatin was absorbed at acid than at neutral $\mathrm{pH}$, but, as can be seen from Fig. 1, the sensitivity of glycolysis to nystatin was not greatly affected. The inhibition did occur more rapidly at $\mathrm{pH} 4.0$ than at $\mathrm{pH} \mathrm{7.0}$; however, the rate

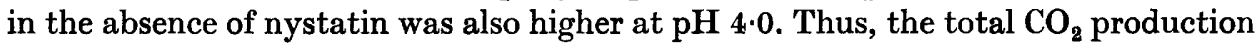
in the presence of differing nystatin levels was similar at both $\mathrm{pH}$ values.

\section{Table 1. The effect of $\mathrm{Na}^{+}$and $\mathrm{K}^{+}$ions on the inhibition of yeast glycolysis by nystatin at different $\mathrm{pH}$ values}

\begin{abstract}
Glycolytic activity is expressed as $\mu \mathrm{l} . \mathrm{CO}_{2}$ evolved in $60 \mathrm{~min} . / 1 \times 10^{8}$ cells. Uptake of nystatin is given as $\mu \mathrm{g} . / \mathrm{mg}$. (dry weight) of yeast in $30 \mathrm{~min}$. (Lampen et al. 1959). Each vessel contained $9 \times 10^{7}$ stationary-phase cells of $S$. cerevisiae LK2 G 12 and $2.8 \mathrm{ml}$. citrate + phosphate buffer, with use of the sodium or potassium salts indicated below. The nystatin and $60 \mu$ mole of glucose were added at $0 \mathrm{~min}$. Final volume $: 3.0 \mathrm{ml}$. Gas phase : $\mathbf{N}_{2}$. Temperature: $30^{\circ}$.
\end{abstract}

$\begin{array}{lrrr}\mu \text { g. nystatin/ml. } & \overbrace{0}^{\text {Glycolysis }} & \begin{array}{c}\text { Uptake } \\ \text { of nystatin }\end{array} \\ \text { pH 4.0 }\left(\mathrm{Na}^{+}\right) & 572 & 69 & 5 \\ \text { pH 4.0 }\left(\mathrm{K}^{+}\right) & 595 & 68 & 3 \cdot 0 \\ \text { pH 7.0 }\left(\mathrm{Na}^{+}\right) & 384 & 89 & 3 \cdot 0 \\ \text { pH 7.0 }\left(\mathrm{K}^{+}\right) & 4.21 & 359 & 0 \cdot 7 \\ & & & 0 \cdot 7\end{array}$

\section{Protection by various cations}

With the A-B cells or stationary-phase cells of strain LK2 G 12, essentially complete protection of glycolysis was obtained when either $\mathrm{K}^{+}$or $\mathrm{NH}_{4}^{+}$was added to sodium citrate + phosphate buffer $(\mathrm{pH} 7)$ system. This is illustrated in Fig. 2. At a concentration of $4 \mathrm{~mm}-\mathrm{KCl}$ or $\mathrm{NH}_{4} \mathrm{Cl}$, good glycolytic activity was usually maintained; in subsequent experiments both were generally added at $9 \mathrm{~mm}$ to insure adequate protection. The addition of $\mathrm{K}^{+}$or $\mathrm{NH}_{4}^{+}$or both to the control vessels caused a slight stimulation of the rate of glycolysis or respiration at $\mathbf{p H ~ 7 \cdot 0 . ~ T h e ~ r a t e ~ o f ~ i n c r e a s e , ~}$ however, was a relatively minor effect when compared with the reversal rate of completely inhibited cells after the addition of $\mathrm{K}^{+}$or $\mathrm{NH}_{4}^{+}$.

$\mathrm{NH}_{4}^{+}$was more effective than $\mathrm{K}^{+}$in protecting log-phase cells or the protoplasts derived from them. Thus, with log-phase cells in sodium citrate + phosphate buffer, a rapid inhibition of glycolysis was produced by $0.25 \mu \mathrm{g}$. nystatin $/ \mathrm{ml}$. The effect of 
$1 \mu \mathrm{g} . / \mathrm{ml}$. was prevented by $\mathrm{NH}_{4}^{+}$but only partially by $\mathrm{K}^{+}$. At $10 \mu \mathrm{g}$. nystatin $/ \mathrm{ml}$., the addition of either ion (or both) yielded only c. $40 \%$ of the uninhibited rate of $\mathrm{CO}_{2}$ production. The superiority of $\mathrm{NH}_{4}^{+}$was equally evident in tests with protoplasts. Glycolysis was rapidly eliminated by $0.25 \mu \mathrm{g}$. nystatin $/ \mathrm{ml}$. ; as shown in Fig. 3, the action of $1 \mu \mathrm{g} . / \mathrm{ml}$. was prevented for at least $60 \mathrm{~min}$. by $\mathrm{NH}_{4}^{+}$, and only delayed by $\mathbf{K}^{+}$.

At $\mathrm{pH} 7 \cdot 0$ respiration of protoplasts was inhibited only when a nystatin concen-

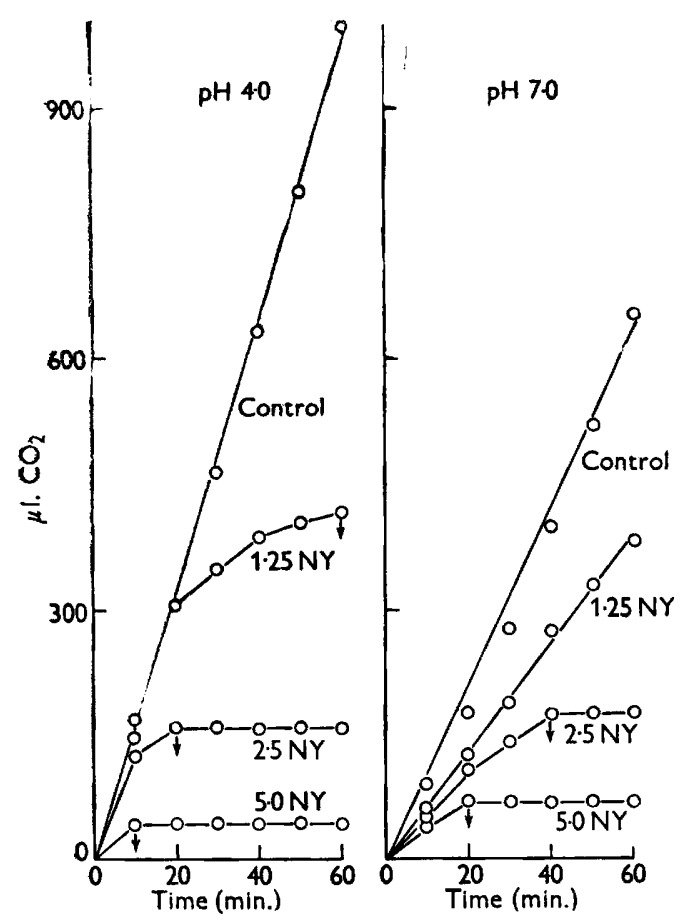

Fig. 1

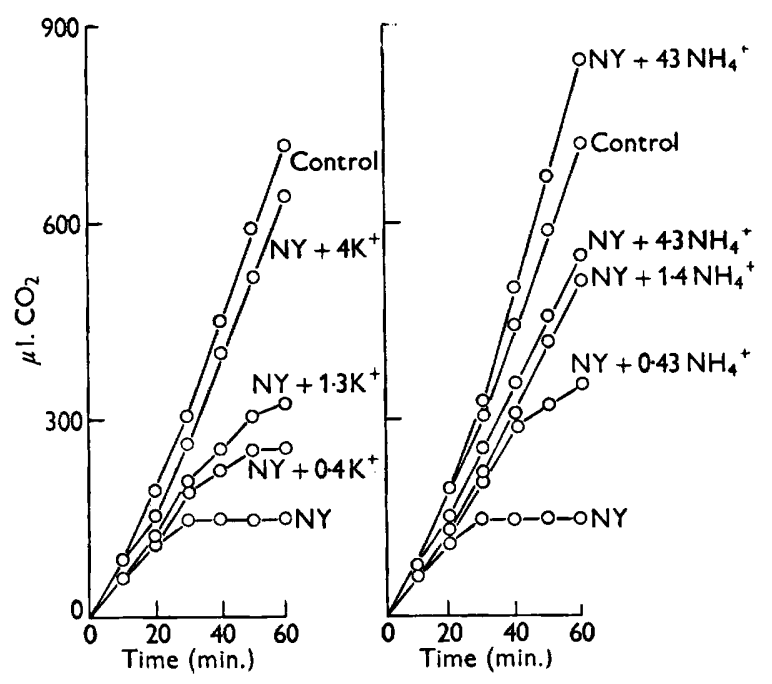

Fig. 2

Fig. 1. Sensitivity of glycolysis to nystatin at neutral and at acid $\mathrm{pH}$. Each vessel contained $2.5 \mathrm{mg}$. (dry weight) of $S$. cerevisiae strain A-B cells, $1.5 \mathrm{ml}$. $\mathrm{pH} 4.0$ or 7.0 sodium citrate + phosphate buffer, and water to bring the final volume to $3.0 \mathrm{ml}$. Nystatin (NY) concentrations are in $\mu \mathrm{g} . / \mathrm{ml}$. The nystatin and $60 \mu$ mole glucose were added from the sidearm at 0 min. Gas phase: $\mathbf{N}_{2}$. Temperature: $30^{\circ}$. The $(\downarrow)$ indicates the point at which metabolism ceased.

Fig. 2. The protection of yeast glycolysis by various concentrations of $\mathrm{K}^{+}$or $\mathrm{NH}_{4}^{+}$against inhibition by nystatin. Each vessel contained $2.5 \mathrm{mg}$. (dry weight) of $S$. cerevisiae strain A-B cells, $1.5 \mathrm{ml}$. sodium citrate + phosphate buffer $(\mathrm{pH} 7), \mathrm{K}^{+}$or $\mathrm{NH}_{4}^{+}$in the indicated final concentrations (expressed in m-equiv./l.), and water to $3.0 \mathrm{ml}$. At $0 \mathrm{~min}$., $120 \mu \mathrm{mole}$ glucose and, where indicated, $15 \mu \mathrm{g}$. nystatin were added from the side-arm. Gas phase : $\mathbf{N}_{2}$. Temperature: $30^{\circ}$.

tration of $20 \mu \mathrm{g} . / \mathrm{ml}$. was attained. Addition of $\mathrm{NH}_{4}^{+}$or $\mathbf{K}^{+}$resulted in temporary protection, but after 40 min. respiration slowed abruptly and it was observed that the protoplasts had lysed.

Respiration by intact cells, either from log- or stationary-phase cultures, was highly resistant to nystatin at neutral $\mathrm{pH}$. No inhibition was observed in sodium 
citrate + phosphate buffer upon the addition of $40 \mu \mathrm{g}$. nystatin $/ \mathrm{ml}$; ; at pH 5.8, logphase cells were inhibited by $20 \mu \mathrm{g}$. $/ \mathrm{ml}$. but stationary-phase cells were only partially inhibited by $40 \mu \mathrm{g} . / \mathrm{ml}$. No protection was achieved by adding a mixture of $\mathrm{K}^{+}$ and $\mathrm{NH}_{4}^{+}$. At $\mathrm{pH} 4 \cdot 0$ respiration was relatively sensitive to nystatin : A-B cells were inhibited by $2 \mu \mathrm{g} . / \mathrm{ml}$. and log-phase LK2G 12 cells by $0 \cdot 25 \mu \mathrm{g} . / \mathrm{ml}$. No significant protection was afforded by $0 \cdot 01-0 \cdot 1 \mathrm{M}-\mathrm{KCl}$ and/or $0.01 \mathrm{M}-\mathrm{NH}_{4} \mathrm{Cl}$.

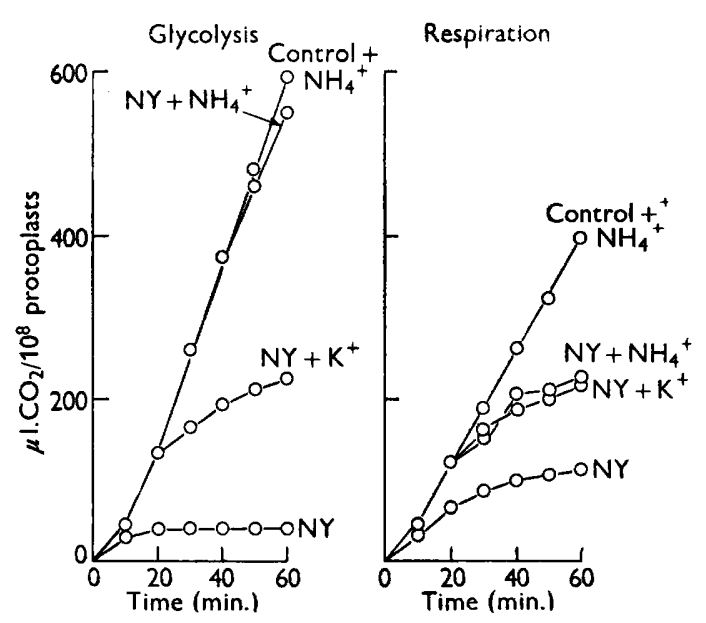

Fig. 3. Protection of glycolysis and respiration in yeast protoplasts. For measurements of glycolysis each vessel contained $8 \times 10^{2}$ protoplasts prepared from $S$. cerevisiae LK2G12, $9 \mathrm{~mm}-\mathrm{KCl}$ or $\mathrm{NH}_{4} \mathrm{Cl}$ (where indicated), $1 \mu \mathrm{g}$. nystatin $/ \mathrm{ml}$. (where indicated), and a gas phase of $\mathrm{N}_{2}$; for respiration, $1.6 \times 10^{8}$ protoplasts, $18 \mathrm{~mm}-\mathrm{KCl}$ or $\mathrm{NH}_{4} \mathrm{Cl}, 20 \mu \mathrm{g}$. nystatin $/ \mathrm{ml}$., and an atmosphere of air were used. All vessels received $2.7 \mathrm{ml}$. sodium citrate + phosphate buffer (pH 7.0) containing $0.82 \mathrm{M}$-mannitol and water to a total volume of $3.0 \mathrm{ml}$. Temperature: $30^{\circ}$. The nystatin and $120 \mu$ mole glucose were added at $0 \mathrm{~min}$.

\section{Reversal of the inhibition of glycolysis}

In cells inhibited by nystatin at neutral $\mathrm{pH}$, glycolysis could be initiated by adding $\mathrm{K}^{+}$or $\mathrm{NH}_{a}^{+}$as long as $\mathbf{1} \mathrm{hr}$. after total inhibition had occurred. From the experiment presented in Fig. $4 \mathrm{~A}$, it may be noted that $\mathrm{CO}_{2}$ production resumed within $10 \mathrm{~min}$. after addition of the supplement and attained a rate approximately that in control vessels.

Reversal of inhibition could also be obtained (Fig. 4B) by the addition of rubidium salts at relatively high levels $(c .50 \mathrm{~mm})$. Lithium chloride and magnesium sulphate were without effect at 9 or $50 \mathrm{~mm}$, and were somewhat toxic at $50 \mathrm{~mm}$ in the absence of nystatin. Calcium, ferrous or manganous salts were inactive at $9 \mathrm{~mm}$. At this value none of these ions prevented complete reactivation when a $\mathrm{K}^{+}+\mathrm{NH}_{4}^{+}$ mixture was subsequently added.

Since 0.1 or $0.2 \mathrm{M}$ sodium salts were present in most experiments, it was conceivable that the inhibition by nystatin was essentially an induced sodium toxicity. When $0 \cdot 1 \mathrm{M}$-imidazole-HCl buffer ( $\mathrm{pH} \mathrm{7 \cdot 0}$ ) was utilized, the sensitivity of glycolysis to nystatin did not differ significantly from that observed in sodium citrate + phosphate buffer or in unbuffered medium. Thus a high concentration of $\mathrm{Na}^{+}$was not essential for the inhibition. 

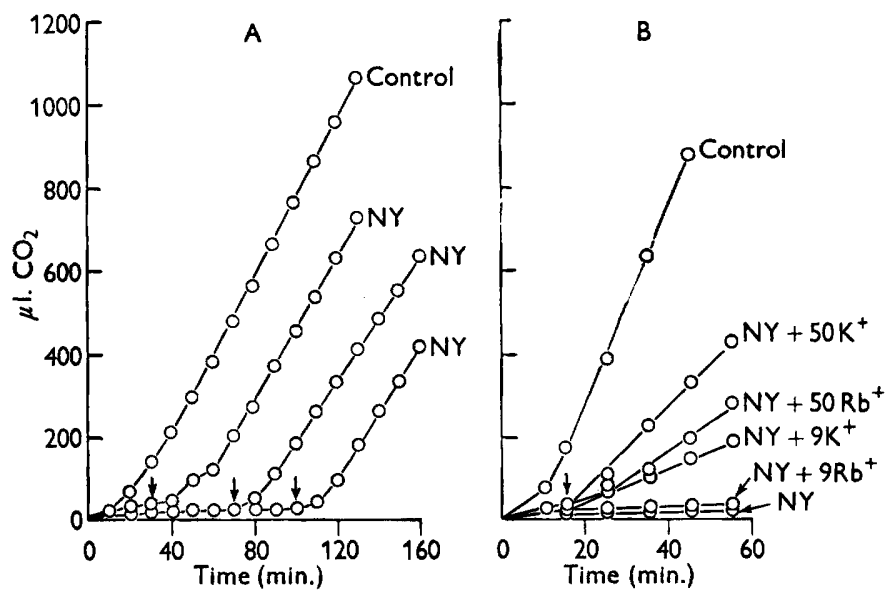

Fig. 4. Reversal by monovalent cations of the inhibition of glycolysis by nystatin. Each vessel contained $1 \times 10^{8}$ cells of $S$. cerevisiae LK2G12 from a log-phase culture and $2.5 \mathrm{ml}$. sodium citrate + phosphate buffer $(\mathrm{pH} \mathrm{7 \cdot 0)}$, containing 0.82 $\mathrm{M}$-mannitol. The nystatin $(3 \mu \mathrm{g}$.) and $120 \mu$ mole glucose were added from the side-arm at $0 \mathrm{~min}$. Final volume: $3.0 \mathrm{ml}$. Gas phase: $\mathbf{N}_{2}$. Temperature: $30^{\circ}$.

A. At 30, 70 or $100 \mathrm{~min}$. as indicated by $(\downarrow), \mathrm{KCl}$ and $\mathrm{NH}_{4} \mathrm{Cl}$ were tipped into individual vessels to yield final concentrations of $9 \mathrm{~mm}$.

B. At $15 \mathrm{~min}$. $(\downarrow)$ various concentrations of $\mathrm{RbCl}$ or $\mathrm{KCl}$ were tipped into individual vessels. Concentrations are expressed as m-equiv./l.

The specific anions present do not appear to be critical. Reversal occurred in test mixtures containing either phosphate, citrate or chloride ions, and the addition of phosphate did not affect the rate at which reversal was attained. The concentration of $\mathrm{K}^{+}$or $\mathrm{NH}^{+}$required for protection was similar whether chloride, nitrate or sulphate salts were used.

Protection or reversal of the inhibition was obtained with a $\mathrm{K}^{+}+\mathrm{NH}_{4}^{+}$mixture only at pH 5.8 and above (Table 2). Conway \& Downey (1950) have reported that the intracellular $\mathrm{pH}$ of yeast is $5 \cdot 8-6 \cdot 2$. At a pH below $5 \cdot 8$ an increase in cellular permeability (induced by nystatin) may produce a rapid acidification of the intracellular space and initiate irreversible damage to the glycolytic system. Consistent

Table 2. Effect of $\mathrm{pH}$ value on the reversal by $\mathrm{K}^{+}$and $\mathrm{NH}_{4}^{+}$of the inhibition of glycolysis by nystatin

Each vessel received either $1 \times 10^{8} \log$-phase cells of $S$. cerevisiae LK2 G12 or $8 \times 10^{7}$ protoplasts and $2.6 \mathrm{ml}$. sodium citrate-phosphate buffer containing $0.82 \mathrm{M}$-mannitol. The nystatin and $120 \mu$ mole glucose were added from the side arm at $0 \mathrm{~min}$. Final volume : $3.0 \mathrm{ml}$. Gas phase: $\mathrm{N}_{2}$. Temperature $: 30^{\circ}$. After $20 \mathrm{~min}$. incubation, glycolysis had ceased in those vessels containing nystatin. $\mathrm{KCl}$ and $\mathrm{HN}_{4} \mathrm{Cl}$ were then added to all vessels in final concentrations of $9 \mathrm{mM}$, and gas evolution was measured for an additional $40 \mathrm{~min}$.

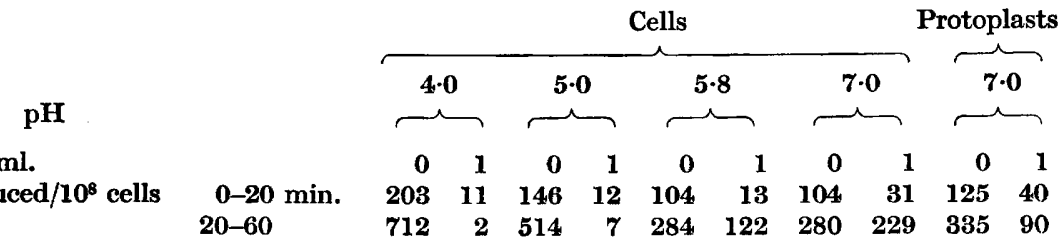


with this suggestion is the observation that cells treated for $15 \mathrm{~min}$. at $\mathrm{pH} 4.0$ with $5 \mu \mathrm{g}$. nystatin $/ \mathrm{ml}$. and then washed, did not resume glycolysis even when tested in the absence of nystatin in potassium citrate + phosphate buffer $(\mathrm{pH} 7 \cdot 0)$ containing $10 \mathrm{mM}^{-\mathrm{NH}_{4}} \mathrm{Cl}$.

The differential effect of $\mathrm{pH}$ on protection by $\mathrm{K}^{+}$is not a function of the conditions under which the original contact between nystatin and the cells occurs. Cells incubated with nystatin $(5 \mu \mathrm{g} . / \mathrm{ml}$.) at $\mathrm{pH} \mathrm{7.0} \mathrm{in} \mathrm{potassium} \mathrm{citrate}+$ phosphate buffer and then washed free of unabsorbed nystatin were inactive when tested at $\mathrm{pH} 4.0$ in $\mathrm{K}^{+}$-buffer; good glycolytic activity was retained at $\mathrm{pH} 7 \cdot 0$ provided $\mathrm{K}^{+}$-buffer was used.

With protoplasts, reversal by $\mathrm{K}^{+}$and $\mathrm{NH}_{4}^{+}$of an established inhibition was incomplete even at $\mathrm{pH} \mathrm{7.0}$ (Table 2), although excellent protection by $\mathrm{NH}_{4}^{+}$was obtained (Fig. 3). The changes produced by nystatin may result in more severe damage to the protoplast membrane than to the membrane of intact cells which have a protective rigid cell wall. In fact, with protoplasts lack of reversal by $\mathrm{K}^{+}-\mathrm{NH}_{4}^{+}$ appeared to correlate with lysis of the preparations.

\section{Effects of nystatin not prevented by $\mathrm{K}^{+}$or $\mathrm{NH}_{4}^{+}$}

Despite the fact that $\mathrm{K}^{+}$and $\mathrm{NH}_{4}^{+}$protect glycolysis against concentrations of nystatin rapidly inhibitory in sodium citrate + phosphate buffers, it is clear from several lines of evidence that these ions do not protect the cells completely from the action of nystatin. High concentrations of nystatin are inhibitory to glycolysis even in the presence of excess $\mathrm{K}^{+}$and $\mathrm{NH}_{4}^{+}$. The mechanism by which this inhibition is produced will be considered in a subsequent publication.

With low concentrations of nystatin ( $5 \mu \mathrm{g}$. or less $/ \mathrm{ml}$.), the addition of $\mathrm{K}^{+}$and $\mathrm{NH}_{4}^{+}$afforded complete protection of glycolysis against the agent but did not prevent its fungicidal action. As is illustrated in Table 3, a decrease of c. 99.99\% in colony-forming units occurred regardless of the presence or absence of the ions.

\section{Table 3. Lack of effect of $\mathrm{NH}_{\mathbf{4}}^{+}$and $\mathrm{K}^{+}$on the fungicidal action of nystatin}

\begin{tabular}{|c|c|c|c|}
\hline \multicolumn{4}{|l|}{$\begin{array}{l}\text { The manometric } \mathrm{m} \\
\text { vessel contained } 2 \cdot 8 \\
\text { phase culture, and } 1 \text {. } \\
\text { were added where in } \\
120 \mu \text { mole glucose we } \\
\text { phase: } \mathrm{N}_{\mathrm{2}} \text {. Temperat } \\
\text { phosphate buffer (pH } \\
\text { containing } 1.5 \% \text { agar. }\end{array}$} \\
\hline$\mu$ g. nystatin $/ \mathrm{ml}$. & Addition & $\mathrm{CO}_{2}$ & Colony count $/ \mathrm{ml}$. \\
\hline None & None & 338 & $9.2 \times 10^{7}$ \\
\hline 5 & None & 80 & $7.5 \times 10^{3}$ \\
\hline None & $\mathrm{NH}_{4} \mathrm{Cl}+\mathrm{KCl}$ & 346 & $6.6 \times 10^{7}$ \\
\hline 5 & $\mathrm{NH}_{4} \mathrm{Cl}+\mathrm{KCl}$ & 348 & $7.5 \times 10^{2}$ \\
\hline
\end{tabular}

Evidence that nystatin initiates a rapid alteration in cellular permeability is presented in Table 4. Glycolysis by the original cells was essentially independent of exogenous $\mathrm{K}^{+}$(Table 1 ). Even with cells grown on the defined medium modified to contain growth-limiting amounts of potassium salts there was only a slight 
stimulation of glycolysis when $9 \mathrm{~mm}-\mathrm{KCl}$ was added to the usual sodium citrate + phosphate buffer ( $\mathrm{pH} 7 \cdot 0)$. In contrast, when cells were incubated with $5 \mu \mathrm{g}$. nystatin $/ \mathrm{ml}$. in potassium citrate + phosphate buffer $(\mathrm{pH} 7 \cdot 0)$ for $30 \mathrm{~min}$., washed quickly with water, and their glycolytic activities again measured, these cells now had an absolute requirement for exogenous $\mathrm{K}^{+}$(Table 4). Respiration, insensitive to nystatin at $\mathrm{pH} \mathbf{7 \cdot 0}$ by direct test, was also totally dependent on added $\mathrm{K}^{+}$. These nystatin-treated cells could also glycolyse or respire actively when resuspended in ammonium citrate-phosphate buffer ( $\mathrm{pH} \mathrm{7.0)}$; in fact, the rates were higher in the presence of $\mathrm{NH}_{4}^{+}$than of $\mathrm{K}^{+}$.

\section{Table 4. Requirement of $\mathrm{K}^{+}$or $\mathrm{NH}_{4}^{+}$for glycolysis and respiration after nystatin treatment}

Treatment (1) $1.4 \times 10^{8}$ cells of $S$. cerevisiae LK2 G12 from a stationary-phase culture were suspended in $3.0 \mathrm{ml}$. of the $\mathrm{K}^{+}$citrate + phosphate buffer $(\mathrm{pH} 7 \cdot 0,175 \mathrm{~m}$-equiv. $\mathrm{K}^{+} / 1$.) in the presence of $60 \mu$ mole glucose and, where indicated, $5 \mu \mathrm{g}$. nystatin $/ \mathrm{ml}$. The test mixture shaken $40 \mathrm{~min}$. at $30^{\circ}$ in an atmosphere of $\mathrm{N}_{2}$.

Treatment (2) The cell samples were washed twice with water and added to Warburg flasks containing $1.5 \mathrm{ml}$. sodium, potassium, or ammonium citrate-phosphate buffer (pH 7.0) in a final volume of $3.0 \mathrm{ml}$. At $0 \mathrm{~min}$. $60 \mu$ mole glucose was added from the sidearm. Gas phase: $\mathrm{N}_{2}$ or air. Temperature: $30^{\circ}$. $\mu$ g. nystatin/ml. during treatment (1)

\begin{tabular}{|c|c|c|c|c|}
\hline Buffer & 0 & 5 & 0 & 5 \\
\hline Treatment (2) & \multicolumn{2}{|c|}{$\mu \mathrm{l} . \mathrm{CO}_{2} / 60 \mathrm{~min}$} & \multicolumn{2}{|c|}{$\mu \mathrm{l} . \mathrm{O}_{2} / 60 \mathrm{~min}$} \\
\hline $\mathrm{Na}^{+}$ & 440 & 12 & 342 & 11 \\
\hline $\mathbf{K}^{+}$ & 850 & 525 & 330 & 230 \\
\hline $\mathrm{NH}_{4}^{+}$ & 880 & 695 & 338 & 306 \\
\hline
\end{tabular}

The growth of yeast is highly sensitive to nystatin at $\mathrm{pH} 7 \cdot 0$, even in the presence of high concentrations of $\mathrm{K}^{+}$and $\mathrm{NH}_{4}^{+}$. For instance, the minimal inhibitory concentration for strain LK 2G 12 was c. $0.5 \mu \mathrm{g}$. nystatin $/ \mathrm{ml}$. in either the crude Wickerham medium (20 m-equiv. $\mathrm{K}^{+} / 1$.) or Vogel's defined medium (36 m-equiv. $\mathrm{K}^{+} / \mathrm{l}$.). If the potassium salts in the latter medium were replaced by sodium salts so that

\section{Table 5. Leakage of $\mathbf{K}^{+}$from yeast cells following treatment with nystatin}

The test mixtures contained $5 \times 10^{8}$ cells of $S$. cerevisiae LK2G12, $15 \mathrm{ml}$. sodium or ammonium citrate + phosphate buffer $(\mathrm{pH} 7 \cdot 0), 1200 \mu$ mole glucose, nystatin where indicated, and water to $30 \mathrm{ml}$. After incubation for $30 \mathrm{~min}$. at $30^{\circ}$ in an atmosphere of $\mathrm{N}_{2}$, the cells were collected by centrifugation, washed once with water, and resuspended in $5 \mathrm{ml}$. of water. The suspensions were placed in a boiling water bath for $3 \mathrm{~min}$., the cellular debris was removed by centrifugation, and the supernatant fluid analysed for potassium. Conventional flame photometric techniques were employed in conjunction with a Beckman spectrophotometer, model B.

$\mu \mathrm{g} . \mathbf{K}+/ \mathbf{m g}$. cells (dry wt.)

$\begin{array}{cccc}\begin{array}{c}\mu \mathrm{g} . \\ \text { nystatin } / \mathrm{ml} .\end{array} & \begin{array}{c}\text { Buffer } \\ \text { cation }\end{array} & \begin{array}{c}\text { Stationary- } \\ \text { phase cells }\end{array} & \begin{array}{c}\text { Log-phase } \\ \text { cells }\end{array} \\ \mathbf{0} & \left(\mathrm{H}_{2} \mathrm{O}\right) & 14 & 8 \\ 0 & \mathrm{Na}^{+} & 9 & 10 \\ 5 & \mathrm{Na}^{+} & \mathbf{9} & 1 \cdot \mathbf{1} \\ 5 & \mathrm{NH}_{4}^{+} & 1 \cdot 0 & -\end{array}$




\section{$K^{+}$and nystatin action}

only a trace of $\mathrm{K}^{+}$was present, the extent and rate of growth were decreased substantially. Nevertheless, under these conditions the concentration of nystatin required to inhibit growth was still one-half that observed with ample $\mathbf{K}^{+}$. The sensitivity of growth was unchanged when, in $\mathbf{K}^{+}$-deficient medium, $\mathbf{N H}_{4}^{+}$was replaced by $1 \%$ Casamino acids (Difco). Thus $\mathrm{K}^{+}$and $\mathrm{NH}_{4}^{+}$are not decisive in determining the sensitivity of growth to nystatin.

\section{Leakage of $\mathrm{K}^{+}$from cells}

Incubation of log- or stationary-phase yeast cells with nystatin produced a rapid decrease in the intracellular concentration of $\mathbf{K}^{+}$. This is illustrated by the experiment (Table 5 ) in which bound $\mathbf{K}^{+}$(not readily removed by washing with water) was measured. The efflux of $\mathrm{K}^{+}$was not prevented by levels of $\mathrm{NH}_{4}^{+}$which completely protected glycolytic activity. Thus $\mathrm{NH}_{4}^{+}$did not prevent the damage to the cell membrane by nystatin.

\section{DISCUSSION}

Previous studies on the inhibition of yeast by nystatin were conducted primarily at acid $\mathrm{pH}$. These experiments focused attention on an irreversible inhibition of glycolytic and respiratory activity as a critical factor in the fungicidal action of nystatin. Evidence is now presented that the metabolic changes are secondary to alterations of the cell membrane. These alterations are themselves apparently irreversible, but can, at appropriate $\mathrm{pH}$ values, produce either a reversible inhibition of glycolysis or the destruction of the enzymes.

The most attractive working hypothesis is that nystatin reacts primarily with the cell membrane. Nystatin can be bound by isolated cell walls (Lampen \& Arnow, unpublished observations), but the critical importance of the membrane is clear since the sensitivity of protoplasts to nystatin is essentially identical with that of the log-phase cells from which they were derived (Sutton, Marini \& Lampen, 1960). The binding of nystatin causes the membrane to become highly permeable to $\mathrm{K}^{+}$and perhaps to other monovalent cations, and glycolysis quickly ceases as a result of the deficiency of $\mathrm{K}^{+}$. At neutral $\mathrm{pH}$, and when the concentration of nystatin does not exceed $10-20 \mu \mathrm{g} . / \mathrm{ml}$., the addition of $\mathrm{K}^{+}$or $\mathrm{NH}_{4}^{+}$will permit glycolysis to resume. There is no evidence for destruction of the glycolytic enzymes under these conditions since essentially complete reactivation with the monovalent cations is possible. The essentiality of $\mathrm{K}^{+}$or $\mathrm{NH}_{4}^{+}$for glycolysis has long been recognized. These ions are required for yeast phosphofructokinase (Muntz, 1947), aldolase (Richards \& Rutter, 1960) and pyruvate kinase (Washio, Mano \& Shimazono, 1959). $\mathrm{NH}_{4}^{+}$is more effective than $\mathrm{K}^{+}$in reactivating phosphofructokinase; this difference may in part account for the superiority of $\mathrm{NH}_{4}^{+}$for nystatin-treated cells. The loss of cellular $\mathrm{K}^{+}$ which occurs in the presence of nystatin does not halt respiration unless the cells are subsequently washed. Since complete reactivation by $\mathbf{K}^{+}$and $\mathrm{NH}_{4}^{+}$can be achieved, an increased membrane permeability appears to be an adequate explanation of the observed inhibition.

The initial interaction of nystatin and the cell membrane at $\mathrm{pH} 4$ may well be identical with that obtained at $\mathrm{pH} \mathrm{7,} \mathrm{since} \mathrm{the} \mathrm{concentration} \mathrm{of} \mathrm{nystatin} \mathrm{required} \mathrm{to}$ inhibit glycolysis or respiration at $\mathrm{pH} 4$ approximates that needed to inhibit glycolysis at $\mathrm{pH} \mathbf{7}$ (in the absence of $\mathrm{K}^{+}$or $\mathbf{N H}_{4}^{+}$). At reactions more acid than the 
usual intracellular pH value of yeast, sudden increase in the permeability of the cell membrane to monovalent cations would produce a rapid acidification of the cell interior. This may activate latent lytic enzymes, as occurs following acidification of animal cells (De Duve, 1957), and thus initiate the decrease in extractable glycolytic enzymes which characterizes the action of nystatin at pH 4.5 (Scholz, Schmitz, Bücher \& Lampen, 1959). It should be noted that the inhibition of glycolysis and respiration is clearly a result of the prior increase in membrane permeability. This change may be the primary event in nystatin action, since an irreversible loss of ability to maintain elevated internal concentrations of critical ions and cofactors would certainly be lethal.

Evidence has been reported by several laboratories that nystatin produces an alteration of cellular permeability with subsequent leakage of internal constituents. A critical role for $\mathrm{K}^{+}$and $\mathrm{NH}_{4}^{+}$has not been previously proposed, however. Osteux, Tran-Van-Ky \& Biquet (1958) noted that the rate of excretion by Candida albicans of the acids of the citric acid cycle and of inorganic phosphate was increased in the presence of nystatin. The leakage of phosphate was correlated with the concentration of nystatin and the time of contact between the cells and the antibiotic. Bradley (1958a) observed a decrease in cellular phosphorus during a $3 \mathrm{hr}$. period following the addition of nystatin, but at shorter intervals actual accumulation of phosphate esters was noted by Scholz et al. (1959), while pyruvate and malate were rapidly released from the cell. Under the conditions of the present experiments, low concentrations of nystatin appear first to cause a deficiency of $\mathrm{K}^{+}$and $\mathrm{NH}_{4}^{+}$. With higher concentrations of nystatin, leakage of various low molecular weight substances probably occurs, since restoration of activity requires the addition of all the cofactors needed in the usual soluble glycolytic system (Lampen \& Arnow, unpublished observations).

Bradley \& Farber (1960) observed that nystatin inhibited fermentation by Candida stellatoidea in various buffers only at relatively acid $\mathrm{pH}(\mathrm{pH} \mathrm{2-5)}$. These workers emphasized the potential role of the anions in determining sensitivity, but the cations employed were not reported. Ribéreau-Gayon, Peynaud, Lafourcade \& Lafon (1958) also reported that nystatin more effectively inhibited glycolysis of Saccharomyces cerevisiae at acid than at alkaline $\mathrm{pH}$, but again these authors did not indicate the cations used in their buffer systems.

Although major attention has centred on the disorganization of cell-wall synthesis by antibacterial antibiotics (Salton, 1960), several agents are believed to affect primarily the cell membrane and hence cellular permeability. Newton (1956) demonstrated this for polymyxin; Anand \& Davis (1960) and Anand, Davis \& Armitage (1960) reported similar results for streptomycin. Gale (1955) offered evidence that $\beta$-propiolactone acts on the cell membrane of yeast. Scharf (1960) has recently observed $\mathrm{K}^{+}$leakage following treatment of yeast with benzalkonium chloride. Nystatin appears to be an excellent example of this type of antibiotic.

This research was supported in part by the National Science Foundation (U.S.A.) and by the Squibb Institute for Medical Research. One of the authors, F. Marini, was a Waksman-Farmitalia Postdoctoral Fellow. 


\section{REFERENCES}

Anand, N. \& Davis, B. D. (1960). Effect of streptomycin on Escherichia coli. Nature, Lond. 185, 22.

Anand, N., Davis, B. D. \& Armitage, A. K. (1960). Uptake of streptomycin by Escherichia coli. Nature, Lond. 185, 23.

Bachmann, B. J. \& Bonner, D. M. (1959). Protoplasts from Neurospora crassa. J. Bact. 78, 550.

Bradley, S. G. (1958a). Effect of nystatin on Candida stellatoidea. Antibiotics \& Chemotherapy, 8, 282.

Bradley, S. G. $(1958 b)$. Interactions between phosphate and nystatin in Candida stellatoidea. Proc. Soc. exp. Biol., N.Y. 98, 786.

Bradley, S. G. \& Farber, P. J. (1960). Interactions among pH, buffer, and nystatin in Candida stellatoided. Antibiotics \& Chemotherapy, 10, 174.

Brown, R. \& Hazen, E. L. (1957). Present knowledge of nystatin, an antifungal antibiotic. Trans. N.Y. Acad. Sci. 19, 447.

CavetT, J. W. (1931). An improved micro Kjeldahl method. J. Lab. clin. Med. 17, 79.

Conway, E. J. \& Downey, M. (1950). An outer metabolic region of the yeast cell. Biochem. J. 47, 347.

De Duve, C. (1957). The enzymic heterogeneity of cell fractions isolated by differential centrifuging. Symp. Soc. exp. Biol. 10, 50.

Donovick, R., Pansy, F. E., Stout, H. A., Stander, H., Weinstein, M. J. \& Gold, W. (1955). Some in vitro characteristics of nystatin (Mycostatin). In Therapy of fungus diseases: an international symposium. Ed. by T. H. Sternberg and V. D. Newcomer. p. 176. Boston: Little, Brown and Co.

GALE, G. R. (1955). The effects of $\beta$-propiolactone on the metabolism of Candida albicans. J. infect. Dis. 96, 250.

GomorI, G. (1955). Preparations of buffers for use in enzyme studies. In Methods in Enzymology. Ed. by S. P. Colowick and N. O. Kaplan, Vol. 1, p. 138. New York: Academic Press, Inc.

Harman, J. W. \& Masterson, J. G. (1957). The mechanism of nystatin action. Irish. J. med. Sci. no. 378, 249.

LAMPEN, J. O., Morgan, E. R. \& Slocum, A. C. (1957). Effect of nystatin on the utilization of substrates by yeast and other fungi. J. Bact. 74, 297.

Lampen, J. O., Morgan, E. R., Slocum, A. \& Arnow, P. (1959). Absorption of nystatin by microorganisms. J. Bact. 78, 282.

Meyer-Rohm, J., HopfF, W. \& LANGe-Brock, T. (1957). Experimentelle Untersuchungen über Wirkungsweise und therapeutische Effekte von Nystatin. Arzneimittel-Forsch. $7, \mathbf{3 5 5}$.

Muntz, J. A. (1947). The role of potassium and ammonium ions in alcoholic fermentation. J. biol. Chem. 171, 653.

Newton, B. A. (1956). The properties and mode of action of the polymyxins. Bact. Rev. 20, 14.

Osteux, R., Tran-Van-Ky \& Biquet, J. (1958). Contribution à l'étude du mode d'action de la nystatin sur Candida albicans. C.R. Acad. Sci., Paris, 247, 2475.

Peynaud, E., Lafourcade, S. \& Lafon, M. (1957). Action des nouveaux antibiotiques antifongiques sur les levures de vins. C.R. Acad. Sci., Paris, 244, 2426.

Ribéreau-Gayon, J., Peynaud, E., Lafourcade, S. \& Lafon, M. (1958). Mode d'action des antibiotiques antifongiques sur les levures. Bull. Soc. chim. Biol., Paris, 40, 189.

Richards, O. C. \& RutTer, W. J. (1960). Studies on the properties and mechanism of action of various aldolases. Fed. Proc. 19, 86.

Salton, M. R. J. (1960). Effects of nutritional deficiencies and antibiotics on cell wall synthesis. In The Bacteria. Ed. by I. C. Gunsalus and R. Y. Stanier, Vol. 1, p. 140. New York: Academic Press, Inc.

Scharf, T. G. (1960). Correlation of the metabolic effects of benzalkonium with its membrane effects in yeast. Fed. Proc. 19, 136. 
Scholz, R., Schmitz, H., Bücher, T. \& Lampen, J. O. (1959). Über die Wirkung von Nystatin auf Bäckerhefe. Biochem. Z. 331, 71.

Sutton, D., Marini, F. \& Lampen, J. O. (1960). Yeast glycolysis: enzyme localization and the site of nystatin action. Bact. Proc. 60, 160.

Vogel, H. J. (1956). A convenient growth medium for Neurospora (Medium N.) Microbial Genetics Bull. no. 13, 42.

Washio, S., Mano, Y. \& Shimazono, N. (1959). Purification and assay method of pyruvate kinase from bakers' yeast. J. Biochem., Tokyo, 46, 1661.

Wickerham, L. J. (1951). Taxonomy of yeasts. Tech. Bull. U.S. Dep. Agric. no. 1029. 